Global Conferences Series:

Social Sciences, Education and Humanities (GCSSSEH), Volume 6, 2020

International Conference Fakultas Tarbiyah dan Keguruan Universitas Islam Negeri Imam Bonjol Padang (ICFTKUINIBP) 2020

DOI: https://doi.org/10.32698/icftk423

\title{
Self Assessment of Freedom to Learn in Higher Education
}

\section{Self Assessment "Merdeka Belajar" pada Perguruan Tinggi}

\author{
Hadeli $^{\mathrm{a}}$, Elismawati1, Hidayat Al Azmi ${ }^{\mathrm{a}}$, Zulvia Trinova ${ }^{\mathrm{a}}$ \\ ${ }^{a}$ Universitas Islam Negeri Imam Bonjol, Padang, Indonesia \\ E-mail: hadelisikumbang@gmail.com
}

\begin{abstract}
Assessment has a very important role in education today. This is because the ability to carry out selfassessments in higher education is one of the implicit goals in it. Although several studies have proven that the application of Self-Assessment will only be truly effective in superior universities, with the concept of "Independent Learning" which has been proclaimed by the Minister of Education and Culture of the Republic of Indonesia, the concept and application of self-assessment is very much needed. This is because the concept of independent learning opens opportunities for students who are not yet categorized as superior to be able to take part in the lecture process at higher tertiary institutions. This of course requires a concept formulation and implementation design that can be applied to higher education. Self-assessment ultimately helps students evaluate, assess quality, the learning process, collect information about themselves and compare it with progress (achievement), and be able to take the next action.Kata
\end{abstract}

Keywords: Self assessment, merdeka learning, higher education

\section{PENDAHULUAN}

Merdeka Belajar adalah program kebijakan baru Kementerian Pendidikan dan Kebudayaan Republik Indonesia (Kemendikbud RI) yang dicanangkan oleh Menteri Pendidikan dan Kebudayaan RI Kabinet Indonesia Maju, Nadiem Anwar Makarim (Sherly, S., Dharma, E., \& Sihombing, H. B., 2020; Ramadania, F., \& Aswadi, D., 2020; Priyotamtama, P. W., 2020). Nadiem Makarim menambahkan fakta bahwa dalam kurun waktu kurang dari 10 tahun saja Indonesia telah melakukan pembaharuan kurikulum sebanyak 3 kali. Hal tersebut dilakukan untuk menjawab kebutuhan Indonesia yang berubah sesuai kemajuan zaman, baik secara intern maupun ekstern. Dengan demikian, Indonesia diharapkan dapat mempersiapkan perserta didik yang memiliki daya saing di masa yang akan datang (Khasanah, 2015). Untuk itu, perlu menjadi perhatian dalam mewujudkan program merdeka belajar yang telah dicanangkan tersebut di lembaga pendidikan.

Merdeka Belajar, sebagaimana yang digagas Mendikbud, berpeluang untuk mempersempit perbedaan kualitas (quality devide) tersebut, melalui sejumlah program intervensi pendidikan yang sedang dan akan dilakukan, terutama dengan akan diperkenalkannya konsep kurikulum pembelajaran yang fleksibel dan beragam, penguatan otonomi dan kapasitas guru (berbasis kebutuhan), kepala sekolah (instructional management) dan teknologi pembelajaran.

Sebagaimana juga dikemukakan Mendikbud Nadiem Anwar Makarim pada forum webinar, yang diselenggarakan Media Indonesia (6/5), "Esensi dari Merdeka Belajar adalah memberikan potensi terbesar untuk para guru dan murid untuk berinovasi dan meningkatkan kualitas pembelajaran secara mandiri; karenanya, pemerataan akses teknologi menjadi suatu hal yang tidak dapat ditawar.

Kehadiran teknologi informasi dan komunikasi di ruang kelas, sayangnya, belum secara otomatis akan menciptakan lingkungan belajar yang kreatif dan inovatif. Untuk mendukung penggunaan teknologi informasi, guru masih perlu menambahkan nilai yang akan dapat menciptakan peningkatan motivasi dan keterlibatan siswa (students engagement) dalam kegiatan pembelajaran. Desain dalam pembelajaran sebagaimana dikehendaki konsep Merdeka Belajar mensyaratkan hadirnya otonomi guru dalam membuat setiap keputusan pembelajaran, dan tersedianya ruang bagi siswa untuk memilih pengalaman pembelajaran 
yang dikehendaki. Untuk itu, guru perlu menyiapkan pilihan pengalaman pembelajaran yang menarik dalam mewujudkan konsep merdeka belajar tersebut.

Dengan konsep Merdeka Belajar pada tahun mendatang, sistem pengajaran akan berubah dari yang awalnya bernuansa di dalam kelas menjadi (sebahagian) di luar kelas. Hal ini tentu membutuhkan kesiapan yang matang dari sebuah lembaga untuk mempersiapkan sumber daya manusia beserta sarana dan prasarana untuk melancarkan dalam mewujudkan merdeka belajar itu secara optimal.

Berdasarkan konsep yang dikemukakan Mendikbud tersebut, diungkapkan 4 Kebijakan Kampus Merdeka, yaitu: (1) Episode 1: asesmen Merdeka Belajar untuk UN-USBN, Zonasi, dan RPP; (2) Episode 2: tema Kampus Merdeka, pembukaan prodi baru, akreditasi, SKS yang dimerdekakan di kampus dan PTN-BH; (3) Episode 3: penataan ulang dan penyaluran dana BOS untuk meningkatkan efektivitas dan kualitas pembelajaran; dan (4) Episode 4: partisipasi satuan dan Forum Organisasi Penggerak Pendidikan (termasuk mitra organisasi) untuk pembangunan Pendidikan Dasar dan Menengah. Satu di antaranya adalah adanya kegiatan dua semester di luar kampus. Kegiatan tersebut meliputi: (1) Magang praktik industri; (2) Proyek desa; (3) Pertukaran mahasiswa; (4) Penelitian; (5) Wirausaha; (6) Proyek independen; (7) Proyek kemanusiaan; (8) Mengajar di sekolah (Siregar, N., Sahirah, R., \& Harahap, A. A., 2020 ; Mastuti, R., dkk., 2020).

Nadiem menegaskan bahwa Ujian Nasional tidak dihapuskan tetapi sistimnya saja yang berubah dengan assesment standar Nasional, medianya tetap menggunakan teknologi, sasarannya tidak untuk menilai prestasi siswa tetapi menilai sekolah secara global (mengetahui data umum), aspek kognitif yang dinilai adalah kemampuan minimum meliputi literasi, numerasi dan aspek lainnya adalah survei karakter.

Kegiatan yang akan dilakukan di luar kampus, sama halnya dengan kegiatan rutin yang telah dilakukan di dalam kampus, maka tentu tetap diperlukan kegiatan penilaian/assessment, karena penilaian bertujuan untuk mengetahui keefektifan kegiatan itu dilakukan, berhasil atau belum optimal.

Setiap kegiatan pembelajaran yang memerlukan penilaian/assessment tersebut, mestinya seiring dengan tujuan dan materi kurikulum. Dengan demikian, dalam upaya untuk meningkatkan semangat belajar peserta didik maka harus seiring antara standar (kompetensi), isi/konten (materi/kurikulum), penilaian, dan strategi pembelajaran. Hal ini bermakna bahwa antara standar, materi, penilaian dan strategi pembelajaran benar-benar saling melengkapi sebagai sebuah sistem yang antara satu aspek bergantung dengan aspek lainnya (Yuliananingsih Y., 2020). Penilaian bukan hanya sebagai bagian dari suatu kegiatan belajar, tetapi penilaian juga dapat meningkatkan proses pembelajaran secara optimal. Pembelajaran yang lebih baik dapat diperoleh melalui konsep merdeka belajar yang telah dicanangkan tersebut.

Merdeka belajar bertujuan untuk membuat pembelajaran lebih bermakna lagi. Adapun secara umum program ini bukan untuk menggantikan program yang telah berjalan, tujuan utamanya adalah memperbaiki sistem yang sudah ada. Merdeka belajar yang digagas Kemendikbud menawarkan proses pembelajaran yang lebih sederhana. Adit memaparkan bahwa penyederhanaan pelaksanaan pembelajaran tersebut seperti: (1) RPP (rancangan pelaksanaan pembelajaran) yang dibuat oleh guru tidak perlu terlalu banyak dan rumit seperti sebelumnya, (2) sistem zonasi dalam penerimaan peserta didik baru yang telah berjalan sejak beberapa tahun lalu tetap dilaksanakan namun lebih luwes dalam pengimplemenmtasiannya, (3) mulai tahun 2021 ujian nasional yang selama ini menjadi beban bagi pelaku pembelajaran diganti dengan asesmen kompetensi minimum dan survei karakter, dan (4) ujian sekolah berstandar nasional (USBN) dialihkan menjadi asesmen berkelanjutan seperti portofolio (tugas kelompok, karya tulis, praktikum, dan sebagainya) (Adit, 2019).

Penilaian dalam merdeka belajar ini diarahkan pada assessment berkelanjutan, maka dapat disepakati bahwa assessment autentik yang pernah diimplementasikan pada kurikulum 2013 masih relevan untuk diintegrasikan dengan program tersebut. Assessment autentik memberikan cara penilaian yang cukup luas terhadap perkembangan siswa. Tidak hanya aspek kognitif yang menjadi acuan utama penilaian, melainkan juga aspek afektif dan psikomotor. Dengan demikian, merdeka belajar memerlukan sistem penilaian tersendiri yang sifatnya lebih sederhana (Sugiri, W. A., \& Priatmoko, S., 2020).

\section{PEMBAHASAN}

Self Assessment merupakan salah satu opsi bentuk penilaian merdeka belajar. Self Assessment atau Self Report Assessment (Popham, 2017) merupakan teknik penilaian dengan cara meminta peserta didik untuk mengemukakan kelebihan dan kekurangan dirinya dalam konteks pencapaian kompetensi. Instrumen yang digunakan berupa lembar penilaian diri menggunakan daftar cek atau skala penilaian (rating scale) yang disertai dengan rubrik (Idris, M. M., \& Asyafah, A., 2020; Putri, P. A., 2020). 
Self Assessment dipertimbangkan efektif untuk menilai/memantau perkembangan mahasiswa yang berada jauh dari jangkauan dosen (Hignasari, L. V., \& Supriadi, M., 2020). Penggunaan metode Self Assessment dilatarbelakangi bahwa penilaian selama ini berpusat pada dosen kadang sering membuat kerepotan dalam menilai dan mahasiswa kurang terlibat, sehingga mahasiswa sebagai obyek penilaian yang seharusnya dapat mengambil manfaat paling besar dari penilaian, ternyata belum mendapatkan feedback yang maksimal dari penilaian tersebut. Self Assessment adalah suatu metode penilaian yang memberikan kesempatan pada peserta didik untuk mengambil tanggung jawab terhadap belajarnya sendiri. Self Assessment melibatkan mahasiswa baik dalam memberikan penilaian maupun menerima penilaian (Shofiyah, H., Wasis, 2013).

Self Assessment dimaksudkan untuk memberikan kesempatan kepada pengguna untuk menilai sendiri kemampaun pemahaman mereka. Dari skor tersebut, maka pengguna akan mampu menilai dirinya sendiri apakah sudah memahami materi tersebut atau belum. Jadi pengajar akan mudah untuk memonitoring pengguna mana yang belum memahami materi, atau yang tidak mengerjakan.

Self assessment ini bertujuan: (1) meningkatkan kesadaran peserta didik tentang proses belajar dan berpikir mereka sendiri (Zohar, 2004). (2) Memberikan arahan untuk pembelajaran di masa depan (Chamot dan O'Malley, 1994). (3) Membuat guru menyadari kebutuhan peserta didik mereka dan memberi mereka materi tambahan untuk meanmbahkan kemampuan mereka terhadap suatu pelajaran (Blanche, 1988). (4) Membantu peserta didik dalam pembelajaran dan memperbaiki diri menuju ke arah tujuan pembelajaran yang lebih baik (Liang, 2006). (5) Merangsang peserta didik untuk mempelajari materi tingkat tinggi sehingga dapat membantu mereka mencapai tingkat keterampilan berpikir akademis yang lebih tinggi (Teh, 2006). (6) Mempromosikan otonomi pelajar dan membawa rasa tanggung jawab dan akuntabilitas kepada siswa (Asadoorian dan Batty, 2005). (7) Meningkatkan pengetahuan peserta didik tentang tujuan belajar mereka sehingga dapat meningkatkan motivasi dan orientasi tujuan mereka dalam belajar (Liang, 2006). (8) Merangsang peserta didik untuk melakukan berbagai strategi pembelajaran dan keterampilan berpikir tingkat tinggi (Chamot dan O'Malley, 1994). (9) Mengembangkan keterampilan dan strategi belajar yang tepat dan mendorong pembelajaran seumur hidup (Zohar, 2004). (10) Membantu peserta didik mendapatkan nilai yang lebih baik (Harris, 1997).

Di sinilah peran pengajar yang selalu memonitoring kegiatan mahasiswa bisa dengan perangkat elearning dalam mewujudkan dalam proses pembelajaran atau diistilahkan dengan Strategi Assessment for learning (AfL). Strategi Assessment for learning (AfL), terkait erat dengan penilaian formatif, bertujuan untuk memungkinkan siswa menilai pembelajaran mereka sendiri secara mandiri, bergerak menuju peningkatan otonomi sebagai pelajar (Swaffield, 2011), dan dapat menjadikan siswa belajar dengan lebih baik.

Penilaian diri siswa merupakan salah satu bentuk penilaian otentik dimana setiap siswa merefleksikan kekuatan dan kelemahannya untuk mengidentifikasi kebutuhan belajar dan memperkuat kelemahan dengan tujuan untuk meningkatkan prestasi mereka (Fitzpatrick, 2006). Bentuk penilaian ini dapat digunakan untuk tujuan formatif dan sumatif. Namun dalam dua penelitian yang dilakukan oleh peneliti ini hanya digunakan untuk tujuan formatif karena sebagian besar peneliti setuju bahwa hal tersebut dapat berguna untuk tujuan formatif dan kurang tepat untuk tujuan sumatif.

Pelaksanaan self assessment dalam penilaian pembelajaran masih menjadi pro kontra di kalangan ahli dan pengajar. Masih banyak pengajar yang khawatir self assessement akan menghasilkan penilaian yang overestimate dan subyektif. Namun berdasarkan penelitian yang telah dilakukan oleh Wilujeng (2014) tentang self assessment sebagai metode evaluasi hasil belajar mahasiswa menunjukkan bahwa nilai mahasiswa yang tinggi pada self assessement juga mendapat nilai tinggi berdasarkan teacher assessment, hasil yang sama juga diperoleh oleh Suarta (2015) melalui penelitian pengembangan yang dilakukan hasil self assessment dapat dipercaya pada hasil kinerja mahasiswa vokasi, pengembangan self assessment untuk memonitor kemajuan mahasiswa jarak jauh.

Berdasarkan penelitian Gumilar (2013) terdapat beberapa kendala dalam pelaksanaan self assessment, di antaranya masalah waktu dan tingkat kejujuran yang masih kurang, serta siswa merasa kurang percaya diri untuk menilai hasil kerjanya sendiri. Oleh karena itu diperlukan cara untuk melakukan penilaian tanpa menghabiskan jam pelajaran di sekolah, tidak menghambat materi-materi yang belum tersampaikan, kendala jumlah siswa yang banyak teratasi dan dapat meminimalisasi tingkat ketidakjujuran siswa serta siswa lebih terbuka dalam menilai hasil kerjanya sendiri.

Penilaian diri siswa sesuai dengan teori konstruktivis yang menganjurkan keterlibatan penuh siswa dalam membangun pengetahuan mereka sendiri. Untuk membangun pengetahuan baru yang sehat, peserta didik harus menilai pengetahuan ini untuk mengisi celah di dalamnya dan untuk memastikan hubungan antara bagian-bagian pengetahuan yang telah diperoleh sebelumnya. Dengan tidak adanya proses peninjauan 
kembali ini, tidak mungkin ada konstruksi pengetahuan yang nyata. Oleh karena itu, penilaian diri dapat dianggap sebagai hal yang penting untuk membangun pengetahuan menajdi lebih baik (El-Qoumy).

\section{SIMPULAN}

Assessment memiliki peranan penting dalam sebuah perguruan tinggi. Penerapan Self Assessment dalam konsep belajar merdeka membuka peluang bagi para mahasiswa untuk dapat mengikuti proses perkuliahan pada perguruan tinggi yang lebih unggul. Untuk itu dibutuhkan rumusan implementasi yang dapat diterapkan pada perguruang tinggi. Self Assessment diharapkan dapat membantu mahasiswa dalam mengevaluasi, menilai kualitas, proses belajar, mengumpulkan informasi tentang diri dan membandingkannya dengan kemajuan (achievement), serta mampu mengambil tindakan berikutnya secara optimal.

Oleh karenanya, lingkungan belajar secara inheren akan lebih menarik dan menyenangkan. Lingkungan belajar yang benar-benar inovatif ialah lingkungan yang melibatkan siswa dengan cara yang mereka aktifkan dan pelajari karena mereka menginginkannya. Oleh karena itu, setiap elemen lingkungan pembelajaran yang inovatif harus dinilai berdasarkan sejauh mana ia berkontribusi terhadap rasa penguasaan, otonomi, keterkaitan/keterlibatan para mahasiswa akan merangsang pembelajaran seumur hidup dan akan menghasilkan pengetahuan (deep learning).

\section{REFERENSI}

Asadoorian, J. and Batty, H. (2005). An evidence-based model of effective selfassessment for directing professional learning. Journal of Dental Education, 69(12), 1315-1323.

Blanche, P. (1988). Self-assessment of foreign language skills: Implications for teachers and researchers. RELC Journal, 19 (1), 75-93.

Chamot, A. and O'Malley, J. (1994). The CALLA handbook: Implementing the cognitive language learning approach. Reading, MA: Addison Wesley.

Fitzpatrick, J. (2006). Self-assessment as a strategy to provide interactive learning within a professional degree programme. Learning in Health and Social Care, 5(1), 23-34.

Harris, M. (1997). Self-assessment of language learning in formal settings. English Language Teaching Journal, 51(1), 12-20.

Hignasari, L. V., \& Supriadi, M. (2020). Pengembangan E-Learning dengan Metode Self Assessment Untuk Meningkatkan Hasil Belajar Matematika Mahasiswa Universitas Mahendradatta. Jurnal Kependidikan, 6(2), 206-219.

Idris, M. M., \& Asyafah, A. (2020). Penilaian Autentik dalam Pembelajaran Pendidikan Agama Islam. Jurnal Kajian Peradaban Islam, 3(1), 1-9.

Khasanah, E. R. (2015). Pelaksanaan Penilaian Autentik pada Kurikulum 2013 di SD Kota Mojokerto. Universitas Negeri Malang.

Liang, J. (2006). Overview of self-assessment in the second language writing classroom. Paper Presented at the 2006 TESOL Convention, Tampa, 22 Florida. Available at: secondlanguagewriting.com/documents/ Overview.Doc. Accessed May 10, 2006.

Mastuti, R., Maulana, S., Iqbal, M., Faried, A. I., Arpan, A., Hasibuan, A. F. H., \& Arifah, F. N. (2020). Teaching From Home: dari Belajar Merdeka menuju Merdeka Belajar. Yayasan Kita Menulis.

https://mediaindonesia.com/read/detail/311863-merdeka-belajar-dan-mutu-pendidikan. Webinar tanggal 5 Juni 2020.

Priyotamtama, P. W. (2020). Buku Ajar Pendekatan Ilmiah Lanjut: Menumbuhkan Daya Imaginasi Mahasiswa. Sanata Dharma University Press.

Putri, P. A. (2020). Implementasi Penilaian Autentik Dalam Pembelajaran Akidah Akhlak Di Mts Negeri 3 Banyumas (Doctoral dissertation, IAIN).

Ramadania, F., \& Aswadi, D. (2020). Blended Learning dalam Merdeka Belajar Teks Eksposisi. Stilistika: Jurnal Bahasa, Sastra, dan Pengajarannya, 5(1), 10-21.

Sherly, S., Dharma, E., \& Sihombing, H. B. (2020, September). Merdeka belajar: kajian literatur. In UrbanGreen Conference Proceeding Library (Vol. 1, pp. 183-190).

Shofiyah, H., \& Wasis. (2013). Penerapan Self Assesment (Penilaian Diri) Pada Kegiatan Praktikum Untuk Meningkatkan Hasil Belajar Siswa Kelas X Sman 1 Sidayu. Inovasi Pendidikan Fisika, 2(3), 139-142 
Siregar, N., Sahirah, R., \& Harahap, A. A. (2020). Konsep Kampus Merdeka Belajar di Era Revolusi Industri 4.0. Fitrah: Journal of Islamic Education, 1(1), 141-157.

Suarta, dkk. 2015. Model Authentic Self -Assessment dalam Pengembangan Employability Skills Mahasiswa Pendidikan Tinggi Vokasi. Jurnal Penelitian dan Evaluasi Pendidikan. ISSN 2338-6061 Vol 19(1) : 46-57

Sugiri, W. A., \& Priatmoko, S. (2020). Perspektif asesmen autentik sebagai alat evaluasi dalam merdeka belajar. At-thullab, 4(1), 53-61.

Teh, S. (2006). Implementing student self-assessment-tools for learning and reflection. EARB and ELTC, 17.

Yuliananingsih, Y. (2020). Kegiatan Tindak Lanjut dalam Pengembangan Asesmen Pembelajaran di MI. eLMuhbib: Jurnal Pemikiran dan Penelitian Pendidikan Dasar, 4(1), 17-30.

Zohar, A. (2004). Higher order thinking in science classrooms: Students' learning and teachers' professional development. Dordrecht: Kluwer Academic Publishers. 